\title{
PENGENALAN SAPTA PESONA WISATA PADA ANAK USIA DINI DI PAUD KUMARA
} ASIH MATARAM 2019

\author{
Oleh \\ Siluh Putu Damayanti ${ }^{1)}$, I Ketut Bagiastra ${ }^{2)}$ \& Lalu Yulendra ${ }^{3)}$ \\ ${ }^{1,2,3}$ Sekolah Tinggi Pariwisata Mataram \\ Email: ${ }^{1}$ sp.damayanti@gmail.com,${ }^{2}$ bagiastraketut@gmail.com \& ${ }^{3}$ laluyulendra@yahoo.co.id
}

\begin{abstract}
Abstrak
Sapta pesona pariwisata merupakan jabaran konsep sadar wisata yang terkait dengan dukungan dan peran masyarakat untuk mewujudkan suasana lingkunga yang kondusif melalui perwujudan tujuh unsur dalam sapta pesona yaitu keamanan, ketertiban, kebersihan, kesejukan ,keindahan, keramah tamahan dan kenangan. Kesehatan adalah modal utama untuk kita melangkah dan beraktifitas. Tanpa kesehatan kita akan kesulitan untuk beraktifitas. Banyak orang yang menginginkan kesehatan namun dalam berpola hidupnya tidak di perhatikan.Pengenalan sapta pesona dapat dilakukan melalui pembiasaan yang dilakukan di sekolah maupun dirumah Penerapan gaya hidup sehat memang seharusnya dilakukan sejak dini. Ini agar kebiasaan dalam menerapkan gaya hidup yang sehat dapat terus dilakukan hingga dewasa. Dengan kebiasaan yang ditanamkan sejak usia anak-anak, tidak akan sulit untuk mempertahankannya saat anak sudah dewasa nanti. Ini penting karena pengenalan sapta pesona pariwista sejak dini akan menjadi fondasi yang kuat bagi perkembangan dunia pariwisata kedepan gaya hidup sehat akan membawa kita pada keadaan tubuh yang sehat. Hal ini disebabkan karena usia anak-anak membutuhkan pendidikan yang sangat mendasar dan sangat menentukan bagi perkembangan anak dikemudian hari,bahkan ada yang berpendapat bahwa usia dini adalah usia emas (golden age ) yang hanya terjadi sekali dalam kehidupan manusia. Metode dan pendekatan yang ada perlu diketahui bahwa kita harus memahami benar metode atau pendekatan yang akan dipakai, karena ini akan berpengaruh terhadap optimal tidaknya keberhasilan pengenalan sapta pesona pariwisata di kalangan anak usia dini .Metode yang digunakan sangatlah bervariasi diantaranya bercerita , bernyanyi, bersajak dan karya wisata.dan paling penting adalah pembiasan prilaku hidup sehat dan menjaga kelestarian lingkungan
\end{abstract}

Kata kunci : Sapta Pesona Wisata, Anak Usia Dini

\section{PENDAHUALUAN}

\section{Analisis Situasi}

Konsep personal hygiene dalam kehidupan sehari-hari merupakan hal yang sangat penting dan harus diperhatikan karena konsep personal hygiene akan mempengaruhi kesehatan seseorang. Kebersihan itu sendiri sangat dipengaruhi oleh nilai individu dan kebiasaan. Hal-hal yang sangat berpengaruh itu diantaranya kebudayaan, social, keluarga, pendidikan, persepsi seseorang terhadap kesehatan (Adams dan Y. Motarjemi, 2003), sehingga bila kita kaitkan dengan pesona pariwisata dengan sapta keindahan dan kebersihan maka Masalah kesehatan adalah suatu masalah yang sangat kompleks yang saling berkaitan dengan masalah http://ejurnal.binawakya.or.id/index.php/MBI lain di luar kesehatan itu sendiri. Pemecahan masalah kesehatan masyarakat, tidak hanya di lihat dari segi kesehatannya sendiri, tetapi harus di lihat dari seluruh segi yang ada pengaruhnya terhadap masalah "sehat sakit" atau kesehatan tersebut. Banyak faktor yang mempengaruhi derajat kesehatan, baik kesehatan individu maupun kesehatan masyarakat. Salah satunya adalah perilaku hidup sehat (personal hygiene dan sanitasi) ( Depkes, 2000).Semua harapan diatas tentu tidak dapat diraih dalam sekejap, terlebih bila kita mengenalkan tentang sapta pesona pariwisata di kalangan anak usia dini harus ada upaya-upaya yang harus dilakukan secara mendasar. Pengenalan sapta pesona ini dapat mulai ditanamkan dikalangan anak-anak

Vol.14 No.1 Agustus 2019 
Spilence mengatakan bahwa konsep pariwisata adalah sebagai perjalanan dari suatu tempat ke tempat lain, bersifat sementara, dilakukan oleh perorangan atau sekelompok orang guna mencari keseimbangan, keserasian,kebahagiaan, dengan lingkungan hidup dalam dimensi sosial,budaya, alam,dan lingkungan ilmu pengetahuan,( Murdana ,2005). Kenapa anak-anak yang disasar untuk penanaman prilaku hidup sehat? hal ini disebabkan karena anak-anak adalah pendidikan yang sangat mendasar dan sangat menentukan bagi perkembangan anak dikemudian hari,bahkan ada yang berpendapat bahwa usia dini adalah usia emas (golden age) yang hanya terjadi sekali dalam kehidupan manusia .Apabila usia dini ini dimanfaatkan dengan menerapkan pendidikan dan penerapan sikap yang baik tentunya kelak ketika dewasa sikap dan moral yang berkembang adalah baik demikian sebaliknya bila pendidikan dan penanaman sikap tidak baik akan berkembang sikap yng kurang baik tentunya .Oleh karena itu pendidikan anakanak adalah investasi yang sangat mahal harganya bagi keluarga dan juga bagi bangsa .Anak anak merupakan generasi penerus keluarga sekaligus penerus bangsa yang akan meneruskan estafet perjuangan para pendahulu kita. Melalui anak-anak diharapkan secara bertahap pemahaman tentang konsep hidup sehat yang ahkirnya akan menjadi tonggak dalam pengenalan sapta pesona dikalangan usia dini.

Tujuan yang hendak dicapai dalam kegiatan pengabdian ini adalah sebagai berikut:

1. Untuk pengenalan sapta pesona pariwisata dikalangan anak usia dini khususnya pada Kelompok bermain dan Taman Kanak Kanak serta Taman penitipan anak

2. Metodeyang digunakan dengan bercerita, bernyanyi, bersajak , karya wisata , dan pembiasaan prilaku sehat melalui rool model dari guru/pengasuhnya

\section{Target Luaran}

Setelah pelatihan melalui pembiasaan berlangsung diharapkan anak-anak di paud Kumara Asih Mataram secara bertahap berprilaku hidup sehat pada kehidupan sehari-

Vol.14 No.1 Agustus 2019 hari dan diharapkan dapat ditularkan pada kalangan anak sebaya mereka, dalam rangka pengenalan sapta pesona pariwisata

\section{Indikator Keberhasilan}

Agar hasil Pelatihan/pembiasaan optimal bisa dicapai, beberapa indikator keberhasilan perlu dicanangkan, antara lain:

a. Jumlah peserta peserta didik yang hadir tidak kurang dari 60 persen

b. Ketercapaian target materi yang direncanakan

c. Kemampuan peserta didik dalam memahami prilaku hidup sehat dengan menunjukkan aksi nyata dari beberapa sikap hidup sehat yang sesuai dengan kemampuan anak-anak.

\section{Manfaat Pelatihan}

Program ini diharapkan dapat memberikan manfaat sebagai berikut :

a. Peningkatan kemampuan anakanak dalam memahami prilaku hidup sehat di di Paud Kumara Asih Mataram.

b. Memotivasi para guru/pendamping agar setiap hari mencontohkan bentuk aksi dari perilaku hidup sehat sehingga dapat meningkatkan kemampuan mereka dalam bidang kesehatan.

c. Hasil pelatihan ini juga dapat digunakan sebagai bahan pertimbangan untuk pengambil kebijakan yang terkait dengan peningkatan kualitas pembelajaran khususnya pada satuan pendidikan anak usia dini.

\section{METODE PELAKSANAAN}

Kegiatan dilaksanakan selama dua bulan, dari Tgl 1 Mei sarmpai dengan 30 Juni 2019, adapun rincian jadwal pelaksanaan adalah sebagai berikut:

http://ejurnal.binawakya.or.id/index.php/MBI

Open Journal Systems 


\begin{tabular}{|c|c|c|c|c|}
\hline No & Hari, Tanggal & Jam & Materi & Pemateri \\
\hline 1 & $\begin{array}{l}\text { Minggu, I bln Mei } \\
2019\end{array}$ & $8.30-10.00$ & Orientasi lapangan & Tim Sosialisasi \\
\hline & & & & \\
\hline 2 & $\begin{array}{l}\text { Minggu, II bln Mei } \\
2019\end{array}$ & & $\begin{array}{l}\text { Pemaparan Materi yang } \\
\text { ditujukan kepada guru } \\
\text { pendamping dan anak didik }\end{array}$ & Tim Sosialisasi \\
\hline 3 & $\begin{array}{l}\text { Minggu, III bln Mei } \\
2019\end{array}$ & & $\begin{array}{l}\text { Sesuai dengan metode yang } \\
\text { digunakan,materi tentang } \\
\text { pengenalan sapta pesona } \\
\text { pariwisata dalam bentuk } \\
\text { nyanyian, cerita, sajakdan } \\
\text { pembiasaan prilaku sehat }\end{array}$ & Tim Sosialisasi \\
\hline 4 & $\begin{array}{l}\text { Minggu, IV bln Mei } \\
2019\end{array}$ & & $\begin{array}{l}\text { Relationship building, } \\
\text { berpedoman pada materi } \\
\text { pembiasaan prilaku sehat dan } \\
\text { pembiasaan menjaga } \\
\text { lingkungan yang dipandu } \\
\text { metode yang telah disepakati }\end{array}$ & Tim Sosialisasi \\
\hline 5 & Minggu I Juni 2019 & - & $\begin{array}{l}\text { Pengulangan metode yang } \\
\text { digunakan,materi tentang } \\
\text { perilaku hidup sehat dalam } \\
\text { bentuk nyanyian, cerita, } \\
\text { sajakdan pembiasaan prilaku } \\
\text { sehat }\end{array}$ & Tim Sosialisasi \\
\hline 6 & & - & $\begin{array}{l}\text { Relationship building, } \\
\text { berpedoman pada materi } \\
\text { pembiasaan prilaku sehat } \\
\text { yang dipadu metode yang } \\
\text { telah disepakati }\end{array}$ & Tim Sosialisasi \\
\hline
\end{tabular}

\section{HASIL DAN PEMBAHASAN}

Hasil kegiatan pengabdian pada masyarakat ini berlangsung dengan baik dan lancar. Kegiatan ini disambut positif oleh Guru dan anak usia dini di lingkungan Paud Kumara Asih, dan melibatkan mahasiswa dalam kegiatan sosialisasi ini. Program sosisialisasi ini disambut baik oleh guru guru pendamping dan orang tua peserta didik, sebab hasil dari kegiatan ini dapat diterapkan langsung dalam kehidupan sehari hari di sekolah maupun dirumah. Hal ini sejalan dengan kondisi perkembangan anak didik pada usia dini sebagaimana kita ketahui pada usia usia tersebut sedang dalam proses meniru, sehingga apa yang orang dewas contohkan akan ditiru pula oleh anak anak, seperti misalnya ketika kita menerpakan komponen sapta pesona tentang keindahan, kebersihan dan kenyamanan, mereka lakukan dengan penuh suka cita karena kegiatan pembiasaan cuci tangan dilakukan setiap hari karena sarana cuci tangan sudah disiapkan pada setiap sudut demikian juga latihan sikat gigi. Disamping itu kegiatan rutin dilakukan dua kali dalam seminggu guru dan mahasiswa yang terlibat dalam pengabdian ini mengajak anak anak untuk menjaga kingkungan dengan membiasakan menanam tanaman hias maupun tanaman obat untuk keluarga seperti seari, laos, kucit, kencur, Lombok pada sudut halaan yang ada di sekitar sekolah , kegiatan sosialisasi ini ditekankan pada kegiatan bentuk aksi dari elemen sapta pesona yang disesuaikan dengan daya tangkap anak ketika menerjemahkan dalam kehidupan sehari harinya di sekolah maupun dirumah. Hasil evaluasi dilapangan setelah sosialisasi dilaksanakan sungguh menggembirakan sebab anak anak dengan kesadarannya menjaga kebersihan lingkungan sekitar dengan bantuan guru pendamping yang selalu mengingatkan mereka, demikian juga ketika kami tanya salah satu orang tua siswa , merka mengatakan bahwa justru anak anak mereka sering protes kalau mereka membuang sampah sembarangan dan lain sebagainya. Intinya apa yang kami sosialisasikan tentang pengenalan sapta pesona pariwisata paling tidak anak paham dan mau melakukan dalam bentuk aksi nyata

\section{PENUTUP \\ Kesimpulan}

Berdasarkan hasil pengenalan sapta pesona pariwisata melalui pembiasaan prilaku hidup sehat di kalangan anak usia dini dapat diselenggarakan dengan baik dan berjalan sesuai dengan rencana kegiatan yang telah dirancang sebelumnya. Kegiatan ini dapat sambutan baik dari para peserta didik, guru guru pendamping dan orangtua siswa dengan tingkat kehadiran mencapai $90 \%$. Kemampuan peserta dilihat dari penguasaan materi cukup baik, hal ini menunjukkan sosialisasi yang diselenggarakan berhasil dan sukses.

Saran

Berdasarkan hasil evaluasi yang telah dilakukan, saran yang bisa disampaikan sebagai berikut:

1. Adanya kegiatan berkelanjutan yang berupa sosialisasi sejenis untuk selalu diselenggarakan secara terus menerus, sehingga pemahaman yang dimiliki oleh anak didik tentang pengenalan sapta pesona pariwisata semakin berkembang.

2. Materi sosialisasi diharapkan terus

Vol.14 No.1 Agustus 2019 
dikembangkan dan dikreasikan dengan baik, sehingga materi sosialisasi lebih menarik dan lebih baik.

\section{DAFTAR PUSTAKA}

[1] Bambang Sujiono,dkk 2015, Metode Pengembangan Fisik, jakarta Universitas Terbuka

[2] Direktur PAUD. 2009. Pedoman Tehnis Pembentukan Pos PAUD, Depdiknas Jakarta

[3] Hurlock, Elizabeth.B.2002. Psikologi Perkembangan. Jakarta: Penerbit Erlangga

[4] Rahayu, Siti. 1998. Psikologi Perkembangan. Jogyakarta :Gajah Mada university Press

[5] Siti aisyah,dkk 2012, Perkembangan dan Konsep Dasar Pengembangan anak usia Dini. Tangerang Selatan Universitas terbuka

[6] Suryani,Luh Ketut.2008. Biarkan Anak Berkembang Wajar, Bekasi :Eviexena Mediatama.

[7] Sunarto.2005. Perkembangan Peserta Didik. Jakarta : PT Rineka Cipta Kusandrini.

[8] ...............2009. Pembelajaran BCCT di TPA $\underline{\text { RSU dr Sutomo Surabaya,. }}$ Surabaya Makalah Pendampingan TPA

[9] Undang Undang No 20 Tahun 2003. Sistin Pendidikan Nasional.. Jakarta : Biro Hukum dan organisasi Sekjen .Depdiknas

[10] http://bbawor.blogspot.Com/2008/08/penan aman nilai moral -untuk anak sejak usia dini

[11]Undang-undang Pariwisata No 10 tahun 2009

[12]Provinsi Nusa Tenggara Barat,2000 , Sepuluh Tahun Pembangunan Pariwisata Nusa Tenggara Barat.

[13]Bagus Ngurah I Gusti, 2002, Masalah Budaya Dan Pariwisata Dalam Pembangunan, Kajian Budaya Universitas Udayana.

[14]Pendit, Nyoman S, 2002, Ilmu Pariwisata Sebuah Pengantar Perdana, Edisi terbaru dengan perbaikan -perbaikan, Jakarta: PT. Pradnya Paramita.

[15] Wariyanta, 2006, Metode Penelitian Pariwisata, Yogyakarta, Penerbit Andi
[16]Pitana I Gde, Surya Diarta I Ketut, 2009, Pengantar Ilmu Pariwisata, Yogyakarta, Penerbit Andi.

[17]Azwar, Azrul. 1990. Pengantar Ilmu Kesehatan Lingkungan. Jakarta:

[18] Mutiara Sumber Widya.

[19]Peraturan Menteri Kesehatan RI No. 304/Menkes/P/IV/1989 tentang

[20]Persyaratan Kesehatan Rumah Makan dan Restoran.

[21] Purnawijayanti, 1999. Sanitasi Higiene dan Keselamatan Kerja Dalam Pengolahan Makanan. Penerbit Kanisius, Yogyakarta.

[22]Richard Sihite, S.Sos, 2000. Sanitation dan Hygiene, Penerbit SIC, Surabaya. 